\title{
Nilai Pendidikan Novel Padang Bulan serta Pemanfaatannya dalam Pembelajaran Bahasa Indonesia di SMP
}

\author{
Ulinnuha Madyananda $^{1)}$, Umi Yaryati ${ }^{2)}$ \\ 1. Mahasiswa Program Doktoral Pendidikan Bahasa Indonesia FKIP Universitas Sebelas Maret \\ E-mail: umadyananda@gmail.com \\ 2. Guru SMP Negeri 1 Adiwerna \\ Email: umiyaryati@gmail.com
}

\begin{abstract}
Abstrak. Penelitian deskripstif kualitatif ini menitikberatkan kajiannya pada nilai-nilai pendidikan apa sajakah yang ingin disampaikan Andrea Hirata dalam Novel Padang Bulan, serta bagaimana pemanfaatannya dalam pembelajaran Bahasa Indonesia di SMP. Data penelitian ini berupa (1) kata, kalimat, atau paragraf dengan paparan berupa monolog, dialog, atau narasi dalam novel Padang Bulan, (2) hasil wawancara dengan guru bahasa Indonesia, dan (3) hasil observasi pembelajaran di kelas VIII G SMP Negeri 1 Malang. Hasil penelitian menunjukkan nilai-nilai pendidikan dalam novel Padang Bulan ini meliputi nilai sosial, nilai ilmiah, nilai moral, dan nilai agama serta layak untuk dimanfaatkan dalam pembelajaran Bahasa Indonesia di SMP.
\end{abstract}

Kata Kunci : nilai-nilai pendidikan novel Padang Bulan, pemanfaatan dalam pembelajaran Bahasa Indonesia

\section{PENDAHULUAN}

Karya sastra adalah suatu fenomena yang diciptakan oleh pengarang sebagai wujud dari ekspresi berdasarkan pengalaman-pengalaman sendiri maupun orang lain. Pengalaman tersebut ditulis sebagai mana adanya untuk dimaknai sebagai bentuk implementasi dari pengungkapan pikiran maupun perasaan yang ada pada diri manusia. Pengungkapan pikiran ke dalam bentuk karya sastra ini melalui proses perenungan akal dan perasaan sehingga menjadikan suatu karya memiliki bobot estetis.

Seperti halnya pendidikan, pada tingkat yang sederhana kesenian dapat menjadi sarana untuk menyampaikan nilai-nilai moral atau pendidikan umum. Dalam sastra lama, dongeng misalnya, mempunyai fungsi didaktis yang kuat untuk menyampaikan nilai-nilai kehidupan kepada anak-anak. Sedangkan dalam sastra modern Indonesia, sastra dapat digunakan sebagai sarana pendidikan untuk memajukan masyarakat (Kladen, 2004:382). Alasannya, ada berbagai persoalan kehidupan yang dihadapi masyarakat yang selayaknya menjadi pemikiran dan perhatian bersama, sehingga seniman tidak pantas merasa dirinya bebas dari tanggung jawab tersebut. Kesenian pun diperlakukan sebagai sarana untuk memajukan masyarakat dan bersifat otonomi tetapi heterogen.

Dalam novel Padang Bulan, nilai-nilai pendidikan yang ingin disampaikan pengarang dimuat di dalamnya. Pengarang tidak hanya ingin mengekspresikan pengalaman jiwanya saja tetapi secara implisit mempunyai maksud dorongan untuk memengaruhi pembaca agar lebih memahami, menghayati, dan menyadari masalah serta ide yang diungkapkan. Pembaca bisa mengambil pelajaran yang terdapat di dalam karya sastra tersebut dengan penuh kesadaran sehingga dapat dijadikan sebagai bahan renungan dalam kehidupan sehari-hari.

Hal senada disampaikan oleh Syam (1986:139140) tentang nilai-nilai pendidikan yang menekankan pada aspek-aspek sebagai berikut: Pendidikan secara praktis tak terpisahkan dengan nilai-nilai terutama yang meliputi kualitas kecerdasan, kerajinan, ketekunan; bahkan nilai yang dijabarkan dalam wujud kelas (tingkat, grade), nilai berupa rank, score, marks. Terlebih lagi nilai pendidikan terutama masalah proses pembinaan nilai-nilai yang bersifat fundamental, seperti: nilai-nilai sosial, nilai ilmiah, nilai moral, nilai agama. Atau yang tersimpul di dalam tujuan pendidikan yakni membina kepribadian ideal.

Nilai pendidikan yang bersifat fundamental inilah yang menjadi tolak ukur dalam kehidupan sehari-hari untuk mewujudkan tujuan pendidikan sebagai pembinaan pribadi yang ideal. Maka nilai Fundamental menurut Syam ini yang akan dijadikan panduan dalam penelitian. Karena nilai-nilai tersebut yang dianggap banyak menyentuh ranah-ranah kehidupan yang bersifat praktis.

Novel Padang Bulan karya Andrea Hirata yang dibahas dalam penelitian ini juga banyak terkandung nilainilai pendidikan yang mampu menjadi penerang bagi 
pembacanya. Andrea Hirata yang memiliki nama lengkap Andrea Hirata Seman Said Harun merupakan novelis muda Indonesia yang cukup dikenal dengan karya berjudul Laskar Pelangi lahir pada tanggal 28 Oktober 1982. Novel-novel buah karya Andrea Hirata yang telah diterbitkan dan Best Seller diantaranya yang terbagi dalam tetralogi Laskar Pelangi, pertama kali diterbitkan tahun 2008 oleh Bentang Pustaka, Yogyakarta, meliputi novel (1) Laskar Pelangi, (2) Sang Pemimpi, (3) Edensor, dan (4) Maryamah Karpov. Novel berikutnya dwilogi Padang Bulan yang terbit pertama kali tahun 2010 oleh penerbit yang sama, meliputi novel (1) Padang Bulan, dan (2) Cinta di Dalam Gelas, selanjutnya Andrea Hirata juga menulis novel Sebelas Patriot, Laskar Pelangi Song Book dan Ayah yang merupakan buah karya yang sangat menakjubkan.

Novel Padang Bulan begitu dekat kaitannya dengan pengungkapan kebudayaan masyarakat Melayu Belitong yang dapat diambil nilai-nilai pendidikannya dalam aktifitas pembelajaran Bahasa Indonesia di sekolah, khususnya tentang novel. Dalam hal ini guru dapat menggunakan novel Padang Bulan sebagai alternatif bahan pembelajaran Bahasa Indonesia materi kesastraan yang digunakan ketika proses belajar berlangsung. Tujuannya agar siswa dapat belajar sastra dengan mengenali nilai-nilai pendidikan yang terkandung di dalam novel tersebut.

Fokus penelitian ini menitikberatkan kajiannya pada nilai-nilai pendidikan apa sajakah yang ingin disampaikan Andrea Hirata dalam Novel Padang Bulan, serta bagaimana pemanfaatannya dalam pembelajaran Bahasa Indonesia di SMP. Nilai-nilai pendidikan yang dimaksud adalah nilai pendidikan yang bersifat fundamental. Tujuan penelitian ini adalah untuk mendeskripsikan nilainilai pendidikan apa sajakah yang ingin disampaikan Andrea Hirata dalam Novel Padang Bulan, serta menjelaskan bagaimana pemanfaatannya dalam pembelajaran Bahasa Indonesia di SMP.

\section{METODE}

Penelitian ini merupakan penelitian deskriptif kualitatif dengan judul Nilai Pendidikan Novel Padang Bulan serta Pemanfaatannya dalam Pembelajaran Bahasa Indonesia di SMP. Metode yang digunakan adalah metode kualitatif, dengan data berupa (1) teks sastra berbentuk kata, kalimat, atau paragraf dengan paparan berupa monolog, dialog, atau narasi yang mencerminkan nilai-nilai pendidikan dalam novel Padang Bulan, (2) data hasil wawancara, dan (3) hasil observasi.

Sumber data yang diteliti berupa (1) data verbal yaitu teks sastra yang terdapat dalam novel Padang Bulan karya Andrea Hirata, (2) guru bahasa Indonesia sebagai informan, dan (3) populasi siswa kelas VIII G SMP Negeri 1 Malang berjumlah 26 siswa yang berasal dari kelas unggulan.

Dalam penelitian ini, yang bertindak sebagai instrumen sekaligus pengumpul data penelitian adalah peneliti sendiri. Dalam hal ini, peneliti bertindak sebagai partisipan penuh dengan diketahui status sebagai peneliti oleh informan dan populasi. Peneliti juga sebagai perencana, pelaksana pengumpulan data, penganalisis, penafsir data, sekaligus pelopor hasil penelitian.

Selain peneliti sebagai instrumen, ada pula instrumen pembantu berupa korpus data, panduan wawancara, dan lembar observasi yang dapat membantu peneliti untuk mempermudah menganalisis dan mengumpulkan data. Korpus data digunakan untuk menggolongkan paparan data berupa bahasa berbentuk monolog, dialog, dan narasi yang mencerminkan nilai-nilai pendidikan dalam novel Padang Bulan berupa nilai sosial, nilai ilmiah, nilai moral, dan nilai agama. Panduan wawancara digunakan untuk mendapatkan informasi dari guru tentang kecocokan/ketepatan pemilihan Standar Konpetensi (SK) dan Kompetensi Dasar (KD) kurikulum KTSP.

Teknik validitas data yang digunakan dalam penelitian ini adalah trianggulasi, yaitu tindakan menguji atau mengecek data temuan dengan temuan lainnya selagi tidak ada kekontrasan atau asal ada dalam kesesuaian antara satu dengan yang lain. Trianggulasi yang digunakan meliputi (1) trianggulasi sumber, (2) trianggulasi metode, (3) trianggulasi teori.

\section{PEMBAHASAN}

\section{Nilai Sosial Novel Padang Bulan}

Nilai sosial dalam novel Padang Bulan karya Andrea Hirata menceritakan tentang hubungan antar sesama di lingkungan masyarakat Belitong. Hubungan-hubungan tersebut seperti sikap saling membantu antara Syalimah dan para penambang timah kepada Zamzami yang tertimbun longsoran tanah di area penambangan timah, sikap saling menolong antara pak tua keturunan Tionghoa kepada Enong ketika sedang terlunta-lunta di Tanjong Pandan untuk mencari pekerjaan, dan sikap Enong kepada Ikal yang sedang dalam kondisi tergantung di gudang bekas tempat pencucian timah ketika akan meninggikan badan dengan cara menggantungkan badannya pada alat peninggi badan.

Sampai di sana, Syalimah mendengar orang berteriak-teriak panik dan menggunakan alat apa saja untuk menggali tanah yang menimbun Zamzami. Para penambang yang tak punya cangkul menggali dengan tangannya, secepat-cepatnya. Syalimah berlari dan bergabung dengan mereka. Ia menggali tanah dengan menggunakan tanggannya sambil tersedak-sedak memanggil-manggil suaminya. Keadaan menjadi semakin sulit karena hujan turun. Tanah yang menimbun Zamzami menjadi lumpur. Para penambang berebut dengan waktu. Jika terlambat, Zamzami pasti tak tertolong dan Zamzami memasuki saat-saat tak tertolong itu. Syalimah menggali seperti orang lupa diri sambil menangis, sampai berdarah ujung-ujung jarinya. (Padang Bulan, hal. 7)

Nilai sosial yang patut untuk ditiru juga dicontohkan seperti rasa saling menghormati yang ditunjukkan tokoh Zinar kepada Ikal sebagai orang yang 
baru dikenal dan sebagai pelanggan di toko tembakau miliknya. Demikian juga sikap penghormatan yang ditunjukkan Ikal kepada Zinar yang telah berhasil meraih piala penghargaan atas kemenangannya dalam beberapa cabang perlombaan menyambut hari kemerdekaan Indonesia.

Selain sikap saling menolong dan saling menghormati, ditunjukkan pula sikap saling menyayangi satu sama lain dalam interaksi sosial. Sikap-sikap seperti rasa simpati dan haru yang ditunjukkan para pedagang pasar ketika melihat Ikal sedang dibonceng menuju Puskesmas karena sakit, parasaan sayang seorang istri kepada suaminya yang ditunjukkan oleh Syalimah dan Zamzami, ayah dan ibu Ikal, serta pasangan tokoh bibik dan paman Ikal yang terlihat saling mengerti dan mengalah merupakan beberapa contoh positif yang patut untuk ditiru.

Beberapa orang sempat bertanya apa yang terjadi. Mereka cemas melihat wajahku yang pucat dan tampak seperti orang yang sakit parah. Detektif $M$. Nur dan Enong mengambil sikap bijak untuk tidak membuka aibku. Dengan kompak mereka mengatakan bahwa penyakit ayanku kambuh waktu aku sedang melamun di dermaga. Orang-orang itu memandangku dengan sedih dan memberiku nasihat yang sangat simpatik padaku bahwa kalau punya penyakit ayan, jangan sering melamun. Mereka berharap aku cepat sembuh. Seorang ibu mengatakan bahwa ia telah kenal denganku sejak aku bayi. Katanya ia dulu suka menimang-nimangku. Katanya, rambutku telah ikal sejak aku kecil, namun ia tak pernah menduga setelah dewasa aku terkena penyakit seperti itu. Disarankannya berbagai ramuan tradisional untukku. Seorang ibu yang lain membelai-belai rambutku. Kupandangi mereka dengan mata yang kuyu. (Padang Bulan, hal. 219)

Hal tersebut seperti disampaikan Siswanto (2008:169) bahwa peserta didik tidak hanya diajak untuk memahami dan menganalisis berdasarkan bukti nyata yang ada di dalam karya sastra dan kenyataan yang ada di luar karya sastra, tetapi juga diajak untuk mengembangkan sikap positif terhadap karya sastra. Pendidikan semacam ini akan mengembangkan kemampuan pikir, sikap, dan keterampilan peserta didik.

Novel Padang Bulan karya Andrea Hirata dapat dimanfaatkan dalam pembelajaran Bahasa Indonesia di SMP karena muatan nilai sosialnya layak untuk diajarkan dalam pembelajaran. Pemanfaatan nilai sosial ini, tepat digunakan dalam pembelajaran pada keterampilan mendengarkan kelas VIII dengan SK 13 Memahami unsur intrinsik novel remaja (asli atau terjemahan) yang dibacakan, pada KD 13.1 Mengidentifikasi karakter tokoh novel remaja (asli atau terjemahan) yang dibacakan. Juga tepat digunakan dalam pembelajaran berbicara kelas VIII pada SK 14 Mengapresiasi kutipan novel remaja (asli atau terjemahan) melalui kegiatan diskusi, pada KD 14.1 Mengomentari kutipan novel remaja (asli atau terjemahan) dan 14.2
Menanggapi hal yang menarik dari kutipan novel remaja (asli atau terjemahan).

\section{Nilai Ilmiah Novel Padang Bulan}

Hasil analisis terhadap nilai ilmiah dalam novel Padang Bulan menunjukkan beberapa sikap ilmiah Ikal yang dicontohkan ketika sedang menimbang-nimbang peluang kemenangannya dalam pertandingan pingpong. Diawali ketika Ikal mulai menghitung kecepatan perpindahan bola pingpong dalam satu kali pukulan yang melesat di atas meja berukuran kurang dari tiga meter dari satu pemain ke pemain lainnya dengan cermat. Kemudian anggapan Ikal atas kemampuan yang harus dimiliki setiap pemain pingpong dalam melirik dan menoleh dengan baik dan tepat, sehingga Ikal merasa yakin untuk memberi nama pada anggapannya tersebut dengan sebutan teori lirikan mata. Hal-hal tersebut menunjukkan kemampan Ikal yang diceritakan dalam novel ini sangat kuat dan menonjol dalam hal logika.

Saranku, jika memilih pemain pingpong, sebaiknya mereka dibariskan dan dilihat kemampuan melirik dan menolehnya. Pedomannya adalah matematika murahan saja, begini, bola pingpong yang dismes pemain RRC meluncur rata-rata dengan kecepatan 150 km/jam. Jangan kejar aku dari mana kudapatkan angka itu. Oleh karena itu, melalui matematika tingkat carik kantor desa, satu manggis, dua manggis, congklak sana, congklak sini, bola itu akan melesat dalam waktu kurang lebih 1/5 detik dari satu pemain ke pemain lainnya di atas meja pingpong yang panjangnya kurang dari 3 meter. Pelajaran moral dari semua itu adalah, barang siapa yang tak punya kecepatan lirik dan kecepatan toleh kurang dari 1/5 detik, mohon tahu diri dan segera mengurungkan niat menjadi pemain pingpong karena tak ada harapan untuk mengalahkan pemain RRC. (Padang Bulan, hal. 176)

Selain sikap ilmiah tersebut, dicontohkan pula sikap ilmiah ketika Ikal sedang berlatih agar bisa bermain catur dalam perlombaan catur menyambut hari kemerdekaan Indonesia. Sikap dan langkah Ikal diawali dengan mulai berusaha memahami diagram catur yang diajarkan oleh Ninochka Stronovsky melalui media jejaring sosial, kemudian Ikal mulai menyelidiki kemampuan lawan dalam bermain catur. Hal tersebut menunjukkan sikap pantang menyerah dan kegigihan Ikal dalam mewujudkan tujuannya dengan sikap-sikap yang ilmiah. Sikap seperti berusaha untuk menjadikan dirinya mampu menguasai suatu bidang tertentu tersebut tepat untuk diajarkan dalam pembelajaran bersastra pada para siswa agar memiliki sikap seperti yang dicontohkan Ikal.

Nochka mengajariku dan Dedektif M. Nur cara memahami dan menulis diagram catur. Ternyata, ibarat sebuah peta, papan catur memiliki kordinat yang jelas dan setiap buah catur punya kode. Perasaanku meluap-luap. Ide yang awalnya hanya sebuah poligon imajiner dan semburan-semburan kegilaan pada satu subuh yang menyiksa dua hari 
yang lalu, kini menjelma menjadi sesuatu yang mulai mengambil bentuk meski untuk satu misi yang muskil. (Padang Bulan, hal. 159)

Tujuannya agar siswa terbiasa bersikap ilmiah dalam menentukan segala tindakannya berdasarkan pada perkiraan kelogisan/ keilmiahan. Seperti yang disampaikan Dimyati dan Mudjiono (2006:80) tentang motivasi belajar, menerangkan bahwa siswa belajar karena didorong oleh kemampuan mental yang berupa keinginan, perhatian, kemauan, atau cita-cita yang bertumpu pada tiga komponen utama motivasi belajar yaitu kebutuhan, dorongan, dan tujuan.

Nilai ilmiah dalam novel Padang Bulan ini tepat untuk diajarkan pada aspek berbicara kelas VIII SK 14 Mengapresiasi kutipan novel remaja (asli atau terjemahan) melalui kegiatan diskusi, pada KD 14.1 Mengomentari kutipan novel remaja (asli atau terjemahan). Dalam hal ini, siswa diajak untuk menemukan hal-hal positif dalam novel Padang Bulan yang dapat memacu kemampuannya untuk berfikir logis dan sikap pantang menyerah. Siswa akan diberikan sebuah kutipan novel Padang Bulan yang menunjukkan hal-hal yang bermuatan ilmu seperti kelogisan, dan keilmiahan dalam bertindak dan bersikap untuk kemudian dianalisis dan diungkapkan pada hal positif apa yang dapat diambil pelajaran dalam kutipan tersebut.

\section{Nilai Moral Novel Padang Bulan}

Dalam novel Padang Bulan banyak ditunjukkan contoh nilai moral seperti menjaga harga diri yang dilakukan Detektif M. Nur kepada kliennya yang merasa terpojok oleh kelakuan istri kliennya sendiri yang telah menceritakan perihal kliennya yang kehilangan gigi palsu, sikap yang ditunjukkan Enong dan Detektif M. Nur yang berusaha menutupi aib Ikal yang dianggap akan gantung diri di gudang bekas pencucian timah, dan persoalan rasa percaya diri yang dialami Ikal karena merasa pendek dan malu ketika mau menemui Zinar untuk pertama kali merupakan beberapa hal yang dapat diambil nilai positifnya dalam pembelajaran sastra.

Tak pernah sebelumnya Enong berkata keras padaku. Sebenarnya aku bermaksud menjelaskan semuanya. Tapi situasiku runyam. Siapapun yang melihatku waktu itu, cecak sekalipun, pasti menduga aku mau gantung diri. Bahwa alat itu sebenarnya untuk meninggikan badan, adalah hal yang sungkan kuungkap. Pilihanku antara disangka mau bunuh diri atau menanggung malu karena mau meninggikan badan dengan cara yang konyol. Aku tahu betul kaumku yang sangat gemar mengejek orang. Jika kejadian di gudang itu terbongkar, aku akan jadi bulan-bulanan seumur hidup. Aih, tak sanggup aku. Maka kupilih diam saja. (Padang Bulan, hal. 220)

Selain itu sikap seperti perasaan rindu kepada orang yang dekat dengan tokoh, kerinduan Syalimah menunggu suaminya pulang bekerja, kerinduan Enong kepada sosok ayahnya yang telah meninggal, dan kerinduan Ikal pada kedatangan A Ling merupakan sikap yang perlu diperkenalkan kepada siswa untuk diberi muatan-muatan positif dalam kehidupan sehari-hari. Sikap seperti hubungan persahabatan yang dijalin Enong dan teman-temannya sewaktu SD, persahabatan Ikal bersama sahabat laskar pelangi, dan persahabatan antara Enong, Detektif M. Nur dan Ikal yang terjalin dengan begitu lekat juga perlu untuk diajarkan kepada siswa agar tumbuh rasa saling menjaga dan menghargai teman.

Dalam novel Padang Bulan ini juga ditunjukkan hubungan baik antar pasangan suami-istri Syalimah dengan Zamzami, ayah dan ibu Ikal, dan pasangan bibik dan paman Ikal yang saling mengerti dan mengalah. Hubungan anakorang tua antara Detektif M. Nur dan ibunya yang sangat dekat, hubungan Ikal kepada Ayahnya yang dianggap sebagai ayah nomor satu di dunia merupakan gambarangambaran positif nilai moral yang ditunjukkan setiap tokoh dalam novel Padang Bulan.

Kemudian, Syalimah tak sabar menunggu suaminya pulang. Ia berdiri di ambang jendela, tak lepas memandangi langit yang mendung dan ujung jalan yang kosong. Ia ingin segera melihat suaminya berbelok dipertigaan jalan sana, pulang menuju rumah. Ia akan menyongsongnya di pekarangan dan mengatakan betapa indahnya sebuah kejutan. Ia mau mengatakan pula bahwa mulai saat itu mereka harus lebih sering memberi kejutan karena kejutan ternyata indah. (Padang Bulan, hal. 6)

Hal-hal tersebut serupa dengan yang diungkapkan Kenny (dalam Nurgiyantoro, 2000:321) tentang moral dalam karya sastra biasanya dimaksudkan sebagai suatu saran yang berhubungan dengan ajaran moral tertentu yang bersifat praktis, yang dapat diambil dan ditafsirkan lewat cerita yang berkaitan dengan pembaca. Ia merupakan petunjuk yang sengaja diberikan oleh pengarang tentang berbagai hal yang berhubungan dengan naskah kehidupan, seperti sikap, tingkah laku, dan sopan santun pergaulan. Ia bersifat praktis sebab petunjuk itu dapat ditampilkan, atau ditemukan modelnya dalam kehidupan nyata, sebagaimana model yang ditampilkan dalam cerita itu lewat sikap dan tingkah laku tokoh-tokohnya.

Nilai moral dalam novel Padang bulan seperti disebutkan di atas tepat untuk diajarkan dalam pembelajaran berbicara kelas VIII semester 2 SK 14 Mengapresiasi kutipan novel remaja (asli atau terjemahan) melalui kegiatan diskusi, pada KD 14.1 Mengomentari kutipan novel remaja (asli atau terjemahan) dan 14.2 Menanggapi hal yang menarik dari kutipan novel remaja (asli atau terjemahan). Dalam hal ini, siswa akan diberikan sebuah kutipan novel Padang Bulan yang menunjukkan berbagai macam nilai moral seperti sikap menjaga harga diri, rasa percaya diri, perasaan rindu, rasa takut, hubungan persahabatan, hubungan suami-istri, dan hubungan antar anak-orang tua 
untuk dianalisis dan diungkapkan hal-hal yang dapat dipelajari dari kutipan novel tersebut.

\section{Nilai Agama Novel Padang Bulan}

Hasil analisis menunjukkan nilai agama dalam novel Padang Bulan ditunjukkan seperti perasaan dosa dan kebesaran Tuhan. Perasaan dosa seperti dicontohkan Ikal atas sikap penentangannya kepada ayah yang membuat Ikal merasa menyesal dan penentangan Ikal pada segala nasihat ibu yang membuatnya sadar betapa nasehat yang bersifat hakikat adalah nasihat yang diberikan ayah dan ibu.

Meski tak pernah sehuruf pun kubantah pendapat Ibu, di dalam diam itu sebenarnya selama ini aku telah menentangnya. Sekarang aku menyesal. Lihatlah aku kini. Tak lebih dari seorang pemimpi yang tak punya pekerjaan. Benar pepatah lama orang melayu: nasihat Ibu bak suara Tuhan. Nasihat Ibu, sering meragukan awalnya, apa adanya, tak ilmiah, tak keren, tak penting, namun diujung sana nanti, pendapat yang hakikat itu pastilah nasihat Ibu. (Padang Bulan, hal. 111-112)

Selain perasaan berdosa, dicontohkan juga sifat kebesaran Tuhan yang diperlihatkan oleh Enong ketika bertemu Ikal di masjid dan memanjatkan doa kepada Tuhan agar Ikal dan sanak familinya senantiasa diberikan jalan yang lurus. Sikap mengagungkan kebesaran Tuhan juga ditunjukkan tokoh Bibik yang selalu berusaha menjadi manusia yang lebih baik dalam soal beribadah. Hal-hal positif seperti inilah yang harus diajarkan kepada siswa dalam proses pembelajaran sastra agar dalam diri siswa tumbuh rasa patuh dalam menjalankan segala apa yang diperintahkan Tuhan dan menjauhi segala yang dilarangNya.

Sekarang, kian hari, Bibi semakin tak tertarik dengan urusan duniawi. Ia adalah tipe orang yang telah menemukan penghiburan di dalam ibadah. Pembicaraan yang menarik baginya hanyalah soal niatnya ke tanah suci lagi, sebuah tempat yang ia rindukan lebih dari tempat mana pun. Bibi telah mapan secara spiritual. Segala nafkah, segala uruan materi, sama sekali bukan lagi soal yang ia ambil pusing. Ia yakin benar akan rezekinya. Grow old gracefully, itulah istilah orang-

orang pintar zaman sekarang bagi orang seperti Bibiku. (Padang Bulan, hal. 169)

Berdasarkan hasil pembahasan terhadap nilai agama dalam novel Padang Bulan ini sudah tepat untuk diajarkan dalam pembelajaran Bahasa Indonesia pada aspek keterampilan mendengarkan kelas VIII semester 2 dengan SK 13 Memahami unsur intrinsik novel remaja (asli atau terjemahan) yang dibacakan, pada KD 13.1 Mengidentifikasi karakter tokoh novel remaja (asli atau terjemahan) yang dibacakan. Guru juga dapat memanfaatkan hasil analisis nilai agama ini dalam pembelajaran berbicara kelas VIII semester 2 SK 14 Mengapresiasi kutipan novel remaja (asli atau terjemahan) melalui kegiatan diskusi, pada KD 14.1
Mengomentari kutipan novel remaja (asli atau terjemahan) dan 14.2 Menanggapi hal yang menarik dari kutipan novel remaja (asli atau terjemahan).

Pada praktiknya siswa akan diberikan sebuah kutipan novel yang menunjukkan nilai-nilai agama untuk dianalisis dan diungkapkan nilai pendidikan yang dapat diambil oleh siswa. Kemudian, siswa diminta untuk menceritakan hasil kerjanya kepada teman sebangku/kelompok lain tentang nilai agama yang telah diperolehnya dalam mengerjakan tugas.

Tujuan pemanfaatan nilai agama dalam pembelajaran bersastra mata pelajaran Bahasa Indonesia ini agar siswa mampu menunjukkan hal-hal yang bersifat mengagungkan kebesaran Tuhan, sikap takut berbuat dosa dan salah, serta mampu mengedepankan etika religius dalam bersikap. Hal tersebut seperti diungkapkan Rosyadi, Mintosih dan Soeloso (1995:90) tentang nilai agama, merupakan sudut pandang yang mengikat manusia dengan Tuhan pencipta alam dan seisinya. Religi merupakan suatu kesadaran yang menggejala secara mendalam dalam lubuk hati manusia sebagai human nature. Religi tidak hanya menyangkut segi kehidupan secara lahiriah melainkan juga menyangkut keseluruhan diri pribadi manusia secara total dalam integrasinya hubungan ke dalam keesaan

\section{IV.SIMPULAN}

Berdasarkan hasil analisis dan pembahasan tentang (1) nilai-nilai pendidikan dalam novel Padang Bulan karya Andrea Hirata, dan (2) pemanfaatannya dalam pembelajaran Bahasa Indonesia di SMP, menunjukkan bahwa terdapat empat kandungan nilai pendidikan dalam novel Padang Bulan yaitu nilai sosial, nilai ilmiah, nilai moral, dan nilai agama serta cocok/tepat untuk dimanfaatkan dalam pembelajaran sastra di SMP kelas VIII semester 2. Secara lebih rinci simpulan penelitian ini sebagai berikut.

Pertama, nilai sosial meliputi segala sesuatu yang berkenaan dengan proses interaksi manusia dalam kehidupan sosial. Nilai-nilai tersebut seperti, saling membantu, menghormati, dan menyayangi satu sama lain. Pemanfaatan terhadap nilai sosial tepat untuk diajarkan dalam pembelajaran Bahasa Indonesia di SMP kelas VIII semester 2 aspek mendengarkan SK 13 Memahami unsur intrinsik novel remaja (asli atau terjemahan), pada KD 13.1 Mengidentifikasi karakter tokoh novel remaja (asli atau terjemahan) yang dibacakan. Juga tepat digunakan dalam pembelajaran berbicara pada SK 14 Mengapresiasi kutipan novel remaja (asli atau terjemahan) melalui kegiatan diskusi, pada KD 14.1 Mengomentari kutipan novel remaja (asli atau terjemahan) dan 14.2 Menanggapi hal yang menarik dari kutipan novel remaja (asli atau terjemahan).

Kedua, nilai ilmiah adalah segala sesuatu yang bersifat ilmu dan dapat diuji ketetapannya secara ilmu. Pemanfaatan terhadap nilai ilmiah tepat untuk diajarkan dalam pembelajaran Bahasa Indonesia di SMP kelas VIII pada SK 14 Mengapresiasi kutipan novel remaja (asli atau terjemahan) melalui kegiatan diskusi, pada KD 14.1 Mengomentari kutipan novel remaja (asli atau terjemahan). 
Ketiga, nilai moral, terdiri dari dua klasifikasi besar (1) hubungan manusia dengan diri sendiri, yaitu nilai yang bersifat melibat ke dalam diri dan kejiwaan seorang individu. Nilai moral yang termasuk kategori ini meliputi harga diri, rasa percaya diri, rindu, dan ketakutan, (2) hubungan manusia dengan manusia lain dalam lingkup sosial dan lingkungan alam, yaitu segala sifat yang melibatkan seluruh interaksi antar manusia. Nilai moral yang termasuk dalam kategori ini meliputi hubungan suami istri, dan hubungan antar anak-orang tua. Pemanfaatan terhadap nilai moral tepat untuk diajarkan dalam pembelajaran Bahasa Indonesia di SMP kelas VIII semester 2 pada SK 14 Mengapresiasi kutipan novel remaja (asli atau terjemahan) melalui kegiatan diskusi, pada KD 14.1 Mengomentari kutipan novel remaja (asli atau terjemahan) dan 14.2 Menanggapi hal yang menarik dari kutipan novel remaja (asli atau terjemahan).

Keempat, nilai agama yang merupakan sistem yang mengatur tata keimanan (kepercayaan) dan peribadatan kepada Tuhan Yang Maha kuasa serta tata kaidah yang berhubungan dengan pergaulan manusia dan manusia serta lingkungan alam. Nilai agama yang masuk dalam kategori ini terdiri atas perasaan dosa, dan kebesaran tuhan. Pemanfaatan terhadap nilai agama tepat untuk diajarkan dalam pembelajaran Bahasa Indonesia di SMP kelas VIII semester 2 pada SK 13 Memahami unsur intrinsik novel remaja (asli atau terjemahan) pada KD 13.1 Mengidentifikasi karakter tokoh novel remaja (asli atau terjemahan) yang dibacakan. Guru juga dapat memanfaatkan hasil analisis nilai agama ini dalam pembelajaran berbicara kelas VIII semester 2 pada SK 14 Mengapresiasi kutipan novel remaja (asli atau terjemahan) melalui kegiatan diskusi, pada KD 14.1 Mengomentari kutipan novel remaja (asli atau terjemahan) dan 14.2 Menanggapi hal yang menarik dari kutipan novel remaja (asli atau terjemahan).

\section{DAFTAR PUSTAKA}

Dimyati \& Mudjiono. (2006). Belajar dan Pembelajaran. Jakarta: PT Rineka Cipta

Hirata, A. (2010). Padang Bulan. Yogyakarta: Bentang.

Kladen, I. (2004). Sastra Indonesia dalam Enam Pertanyaan; Esai-esai Sastra dan Budaya. Jakarta: PT Pustaka Utama Grafiti.

Nurgiyantoro, B. (2000). Teori Pengkajian Fiksi. Yogyakarta: Gajah Mada University Press.

Rosyadi, S. Mintosih, \& Soeloso. (1995). Nilai-nilai Budaya dalam Naskah Kaba Anggun Nan Tungga Si Magek Jabang: Episode Ke Balai Nan Kodo Baha. Jakarta: CV Dewi Sri.

Siswanto, W. (2008). Pengantar Teori Sastra. Jakarta: PT Grasindo.

Syam, M.N. (1986). Filsafat Kependidikan dan Dasar Filsafat Kependidikan Pancasila. Surabaya: Usaha Nasional. 